\title{
Evaluation of seeding rates of rice nursery on seedling vigour and its effect on crop productivity under system of rice intensification
}

\author{
Ranu Pathania*, J. Shekhar, S. S. Rana and Saurav Sharma \\ Department of Agronomy, Forages and Grassland Management, Chaudhary Sarvan Kumar Krishi Vishvavidhalaya, \\ Palampur-176062 (Himachal Pradesh), INDIA \\ ${ }^{*}$ Corresponding author. E-mail: ranu44raone@gmail.com
}

Received: April 1, 2016; Revised received: September 19, 2016; Accepted: November 28, 2016

\begin{abstract}
Four seeding rates $\left(25,30,35\right.$ and $\left.40 \mathrm{~g} / \mathrm{m}^{2}\right)$ of rice in nursery were tested for seedling vigour recorded at 10, 17 and 24 DAS at Malan during 2013 and 2014. The seedling vigour so obtained in nursery was subsequently evaluated in field during kharif 2013. Thus twenty four treatments comprised of combinations of three seedling ages $(10,17$ and 24 days $)$ and two spacings $(20 \times 20 \mathrm{~cm}$ and $20 \times 15 \mathrm{~cm})$ in main plots and four seedling vigour from four seeding rates $\left(25,30,35\right.$ and $\left.40 \mathrm{~g} / \mathrm{m}^{2}\right)$ in sub plots were evaluated in split plot design. Seedling shoot length under all seeding rates $\left(25-35 \mathrm{~g} / \mathrm{m}^{2}\right)$ was significantly higher compared to check $\left(40 \mathrm{~g} / \mathrm{m}^{2}\right)$ during 2013 . In the next year, shoot and root length $\left(30-35 \mathrm{~g} / \mathrm{m}^{2}\right)$, tiller per seedling and leaves per seedling $\left(25-30 \mathrm{~g} / \mathrm{m}^{2}\right)$ of 24 days nursery was significantly higher over check $\left(40 \mathrm{~g} / \mathrm{m}^{2}\right)$. Plant height, tillers, leaves and dry matter accumulation were significantly higher when younger seedlings aged 10 and 17 days were used. The crop raised using 10 days old seedlings matured 3-5 days earlier than 24 days old seedlings. Wider spacing resulted in more plant height, tillers, leaves and dry matter accumulation. Seedlings from 25,30 and $35 \mathrm{~g} \mathrm{seed} / \mathrm{m}^{2}$ resulted in significantly taller plants than $40 \mathrm{~g} / \mathrm{m}^{2}$. The seeding rate, seedling age and plant spacing did not significantly influence rice productivity thereby permitting flexibility to the rice farmers in the adoption of these factors.
\end{abstract}

Keywords: Seeding rates, Seeding ages, Seedling vigour, Spacing, System of rice intensification

\section{INTRODUCTION}

Rice forms staple food for more than half of the world population. Globally, it occupied an area of 164.3 million hectare with a production of 744.9 million tonnes of paddy in 2013 (Anonymous, 2014). In India, rice the most important and extremely grown food crop, occupied 42.81 million hectare of land and produced 143.96 million tonnes paddy (95.97 million tonnes rice) (FAO, 2013). In Himachal Pradesh also, rice is one of the important cereal crops next to wheat and maize. The crop is cultivated from foothill plains to an altitude of $2290 \mathrm{~m}$ above mean sea level covering an area of 76.7 thousand hectare with total rice production of 118.28 thousand tonnes (Anonymous, 2012-13). At the current rate of population growth, India has to produce about 130 million tonnes of rice by 2025 to feed the growing population. Meeting the targeted demand of food grains is a challenging task for the policy makers, researchers and all other stakeholders. To safeguard and sustain the food security in India, it is therefore, imperative to explore and evaluate such technologies which may increase the productivity of rice under situations of dwindling resource base particularly when there is little scope of horizontal or lateral expansion. Growing rice by System of Rice Intensification (SRI) is a novel approach of rice cultivation which saves water and other inputs (Satayanarayana et al., 2007). Young seedlings prior to the start of the $4^{\text {th }}$ phyllochron of growth ( $<15$ days) possess higher tillering potential which drastically decreases with advancing age. Transplanting at wider spacing relieves the plant of adverse effects of closer spacing viz., severe competition between plants resulting in poor tillering; square geometry gives room for profuse root and tiller growth through more efficient harvest of solar energy and other growth resources, achieving 'the border effect' throughout the whole field (Satayanarayana et al., 2007). Seedling vigour is an important contributor to subsequent tillering quality and yield of rice (TeKrony and Egli, 1991). It is found to be associated with the plant viability, height, thickness of stems and uniformity (Matsuo and Hoshikawa, 1993). These above and below-ground characteristics of rice plants, before and after transplanting, vary with seedling age (Himeda, 1994), growing environment (Kordon, 1974) and seeding rate (Sasaki, 2004). Though, the system of rice intensification is a set of principles based on the alleged synergy among several agronomic practices and their interaction with crop biophysical environment and management (Menete et al., 2008), the optimum values of each one of these practices may vary with location. Since, working out these optima on the basis of a single experimentation involving so many 
practices was not practically feasible, the present study had, therefore, was planned to refine only some of the most important SRI components viz. use of young healthy seedlings and optimization of the rice plant spacing.

\section{MATERIALS AND METHODS}

The field investigation was carried out during kharif 2013 and 2014 at the experimental farm of CSK Himachal Pradesh Krishi Vishvavidyalaya, Rice and Wheat Research Centre, Malan $\left(32^{\circ} 07^{\prime} \mathrm{N}, 76^{\circ} 23^{\prime} \mathrm{E}\right.$ and $950 \mathrm{~m}$ altitude) in North Western Himalayas. The region is endowed with mild summers and cool winters. The soil was silty clay loam, moderately acidic in reaction ( $\mathrm{pH} 5.72)$, medium in organic carbon $(0.58 \%)$, available $\mathrm{N}\left(\mathrm{KMNO}_{4}\right.$ method) (Subbiah and Asija 1956), $\mathrm{P}$ (Olsen method) (Olsen et al., 1954) and K (Neutral normal ammonium acetate extraction method (AOAC, 1970)) content of 314.9, 24.2 and $232.2 \mathrm{~kg} / \mathrm{ha}$. During the season (June to September, kharif 2013), the crop experienced well distributed rainfall of 2323.5 in133 days. Prior to the commencement of the present study, the field was under rice (kharif 2012) -wheat (rabi 2012-13) cropping. The field experiment was conducted in split plot design during kharif 2013 with three replications. The six combinations of three seedling ages (10,17 and 24 completed days) and two plant spacings $(20 \times 20 \mathrm{~cm}$ and $20 \times 15 \mathrm{~cm})$ were allocated to the main plots and seedlings of variable vigour obtained from various seeding rates $(25,30,35$ and $40 \mathrm{~g} /$ $\mathrm{m}^{2}$ ) in nursery to four sub plots. The normal seed (dry) of HPR 2612, a recommended scented rice variety treated with Bavistin (400:1) was sown in rows $10 \mathrm{~cm}$ apart using preplanned seeding rates (viz., 25, 30, 35 and $40 \mathrm{~g} / \mathrm{m}^{2}$ ) in distinct seed beds on $16^{\text {th }}$ June, 2013. The nursery beds were fertilized using $6.5 \mathrm{~g}$ Urea and 7.5 g IFFCO (12:32:16) per $\mathrm{m}^{2}$ which were drilled in rows prior to sowing of seed. For ensuring proper weed control in nursery, the beds were sprayed with butachlor $1.5 \mathrm{~kg} / \mathrm{ha}$ immediately after sowing (Reddy,2004). Whole of recommended P and K (17.46 and $33.2 \mathrm{~kg} / \mathrm{ha}$, respectively) and half of $\mathrm{N}(45 \mathrm{~kg} / \mathrm{ha})$ were applied as basal dose at the time of puddling using IFFCO (12:32:16), muriate of potash and urea. Remaining half of the nitrogen was top dressed through urea in two equal splits each at tillering and panicle initiation stages of rice. The transplanting operation was carried out on three different dates viz., $27^{\text {th }}$ June, $4^{\text {th }}$ and $11^{\text {th }}$ July, 2013 and 2014 as per the requirement of the experiment to transplant 10, 17 and 24 days old seedlings. The observations on seedling vigour viz., shoot length, number of leaves, root length, fresh and dry weights of seedling shoots and roots and number of tillers were recorded on 20 randomly selected seedlings immediately after their uprooting for transplanting in the main field experiment. The statistical analysis in respect of nursery data obser- vations (shoot length/root length, number of tillers and number of leaves) was done using student's t-test for unpaired observations comparing specific treatment with the check viz., $40 \mathrm{~g}$ seed $/ \mathrm{m}^{2}$ at a time. On the other hand, the combined fresh and dry weights of all twenty seedlings shoot and root component were recorded as single value without any statistical analysis. The plots were kept moist by regular watering as per requirement else the water level was maintained at 3-4 $\mathrm{cm}$ depth if available through rainfall. After panicle initiation, submergence up to $5 \mathrm{~cm}$ was followed. The weeds were controlled by using butachlor 5G@1.5 kg a.i/ha 4-5 days after transplanting followed by one hand weeding one month after transplanting.

\section{RESULTS AND DISCUSSION}

Effect on seedling vigour: The seedlings shoot length under the seeding rates $25-35 \mathrm{~g} / \mathrm{m}^{2}$ was significantly higher compared to standard check of $40 \mathrm{~g} / \mathrm{m}^{2}$; the differences being highly significant (1\% level) at all seedling ages from 10-24 days with few exceptions under 10 days old seedlings. Seedling root length under different seeding rates did not differ significantly for 10-17 days old seedlings, but the results were inconsistent in respect of 24 days old seedlings. Number of tillers/seedling and number of leaves/seedling were also not significantly influenced by different seeding rates. Fresh and dry weights of shoot and root components as well as root: shoot ratio of seedlings were numerically lower under seeding rate of $40 \mathrm{~g} / \mathrm{m}^{2}$ (check), the results being inconsistent for the remaining seeding rates ranging from $25-35 \mathrm{~g} / \mathrm{m}^{2}$. Whereas during next year of seeding, seedling s' shoot length of $30-35 \mathrm{~g} / \mathrm{m}^{2}$ nursery is significantly higher at $1 \%$ level except during 17 days where at $5 \%$ only for $35 \mathrm{~g} / \mathrm{m}^{2}$. Root length having similar result like seedling s' shoot length except during 24 days nursery, when $25 \mathrm{~g} / \mathrm{m}^{2}$ nursery seeding rate had root length significantly higher than others. Among the number of tillers and leaves per seedling plant, the significant results were obtained at 24 days nursery growth stage where $25-35 \mathrm{~g} / \mathrm{m}^{2}$ nursery seeding rate had higher tillers and leaves than $40 \mathrm{~g} / \mathrm{m}^{2}$ (check) seeding rate at 5\% level (Table 1). Lima et al. (2010) documented similar findings under a plastic tunnel and revealed that tillering decreased as seeding density increased, with greater participation of the main stems; however, this did not result in increased yield, due to the plasticity shown by rice plants in influencing yield components.

Growth: Plant height was significantly affected due to seedling ages (Table 2). Younger seedlings (10 or 17 days old) resulted in significantly taller rice plants than older ones (24 days old). This was probably when a seedling is transplanted carefully at the initial growth stage, the trauma due to root damage caused during uprooting is reduced which stimulate increased cell division causing more stem elongation. These results 


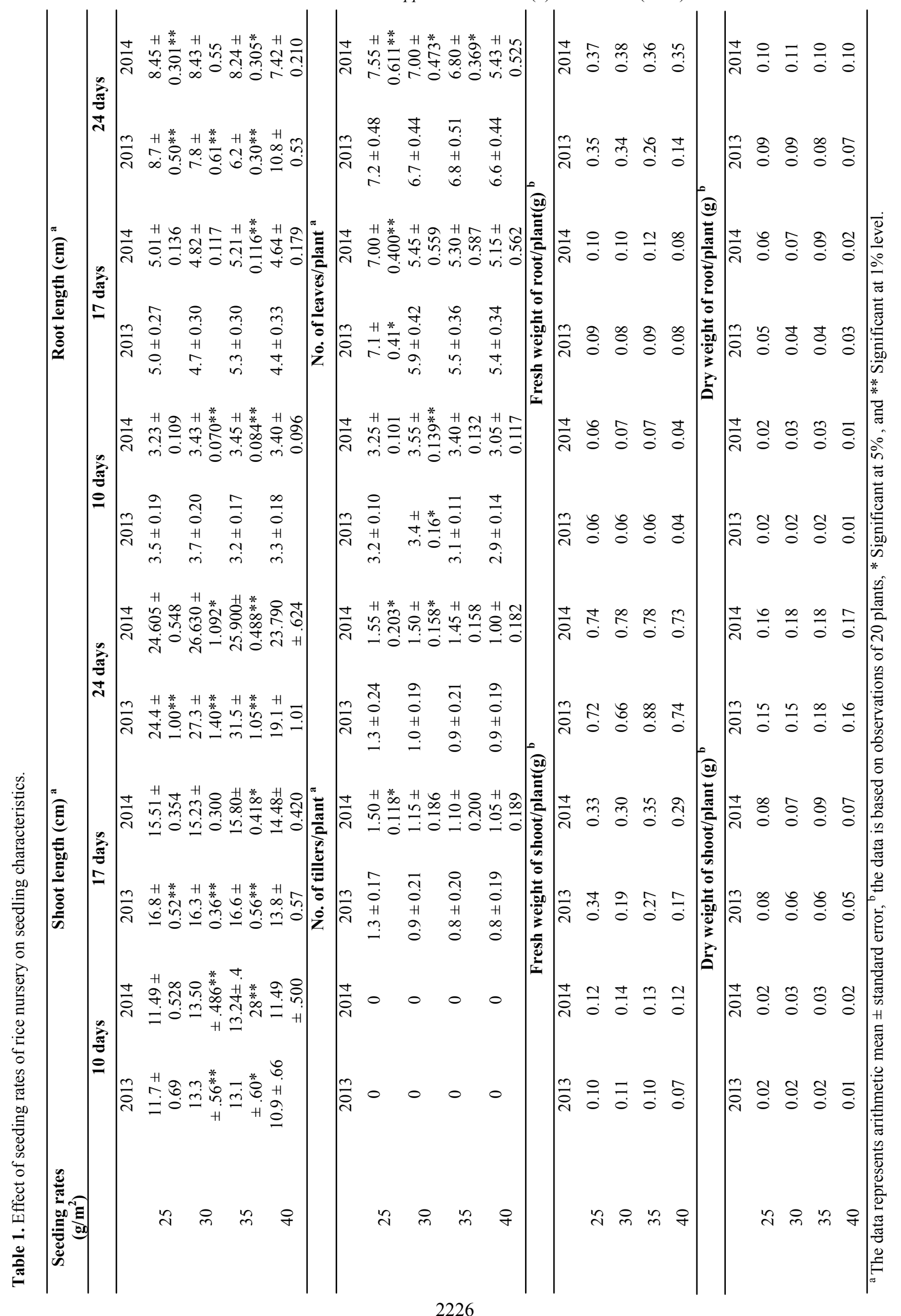




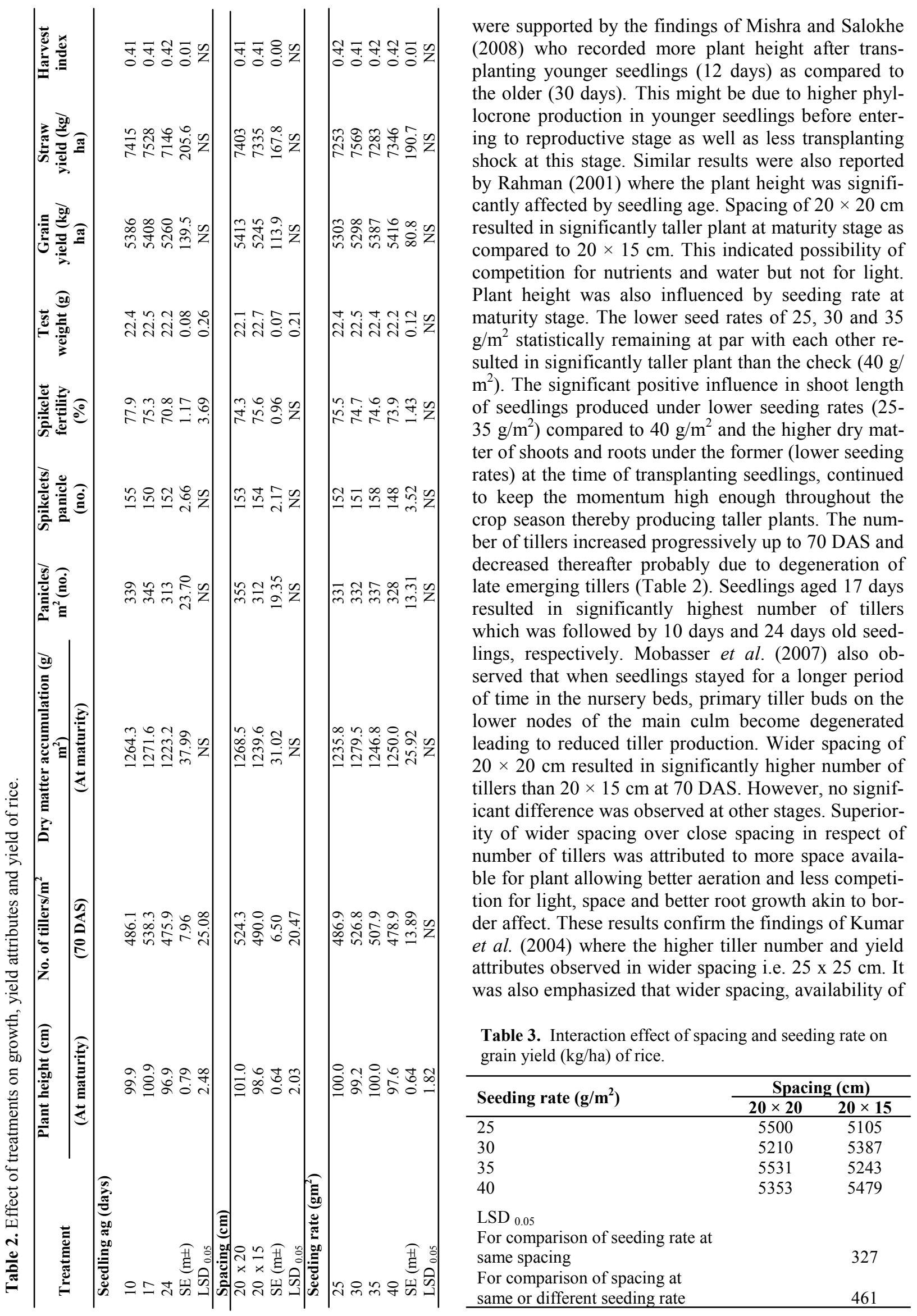


Table 4. Economics of treatments.

\begin{tabular}{|c|c|c|c|c|}
\hline Treatment & $\begin{array}{c}\text { Cost of cultivation } \\
\text { (Rs/ha) }\end{array}$ & $\begin{array}{c}\text { Gross return } \\
\text { (Rs/ha) }\end{array}$ & $\begin{array}{c}\text { Net return } \\
\text { (Rs/ha) }\end{array}$ & B:C ratio \\
\hline \multicolumn{5}{|c|}{ Seedling age (days) } \\
\hline 10 & 32143 & 124220 & 92077 & 3.87 \\
\hline 17 & 31774 & 124854 & 93080 & 3.93 \\
\hline 24 & 31355 & 121181 & 89827 & 3.87 \\
\hline $\mathrm{SE}(\mathrm{m} \pm)$ & - & 3127 & 3086 & 0.09 \\
\hline $\operatorname{LSD}_{0.05}$ & - & NS & NS & NS \\
\hline \multicolumn{5}{|l|}{ Spacing (cm) } \\
\hline $20 \times 20$ & 31098 & 124786 & 93689 & 4.01 \\
\hline $20 \times 15$ & 32698 & 121153 & 88456 & 3.70 \\
\hline $\mathrm{SE}(\mathrm{m} \pm)$ & - & 2553 & 2519 & 0.07 \\
\hline $\operatorname{LSD}_{0.05}$ & - & NS & NS & 0.24 \\
\hline \multicolumn{5}{|c|}{ Seeding rate $\left(\mathrm{g} / \mathrm{m}^{2}\right)$} \\
\hline 25 & 32115 & 122233 & 90118 & 3.81 \\
\hline 30 & 31936 & 122622 & 90686 & 3.84 \\
\hline 35 & 31642 & 124055 & 92413 & 3.92 \\
\hline 40 & 31336 & 124763 & 93428 & 3.98 \\
\hline $\mathrm{SE}(\mathrm{m} \pm)$ & - & 1777 & 1753 & 0.05 \\
\hline $\operatorname{LSD}_{0.05}$ & - & NS & NS & NS \\
\hline
\end{tabular}

solar radiation, medium temperature, soil aeration, and nutrient supply promote shorter phyllochrons which increase the number of tillers in the rice plant. Seeding rate did not influence production of tillers on unit area basis at 70 DAS stage.

The amount of dry matter production depends on effectiveness of photosynthesis of crop and furthermore, on plants whose vital activities are functioning effectively. Dry matter accumulation by shoots increased progressively up to the crop maturity. Statistically, 17 days seedlings accumulated significantly higher dry matter followed by 10 and 24 days old seedlings, respectively at all stages except maturity. Similarly, More et al. (2007) reported that planting younger rice seedlings of 15 days led to significant increase in dry matter production as compared to use of older seedlings of 20 and 28 days age and the extent of increase was 9.62 and $18.80 \%$, respectively. Plant spacing had no effect on dry matter accumulation at all stages except 100 days stage when wider spacing of $20 \times 20 \mathrm{~cm}$ resulted significantly higher dry matter accumulation than $20 \times 15 \mathrm{~cm}$ spacing. Higher total dry matter production under wider spacing was explained due to increase in number of tillers in rice as reported earlier by Rajesh and Thanunathan (2003). The effects of seeding rates on dry matter accumulation, though significant at most of the growth stages in rice except maturity, were quite inconsistent. However, in general, $35 \mathrm{~g} / \mathrm{m}^{2}$ seeding rate resulted in significantly higher dry matter accumulation than other seeding rates. Greater dry matter production might be due to the contribution of greater number of tillers/area and leaf area index.

Yield attributes and yield: A perusal of the data revealed that seedling age significantly influenced the spikelet fertility and test weight but had no effect on number of panicles $/ \mathrm{m}^{2}$ and the number of spikelets per panicle. Ten days old seedling remaining at par with 17 days old seedlings resulted in significantly higher spikelet fertility than 24 days old seedlings. Low level of spikelet fertility ranging from 70.8 to $77.9 \%$ in present experiment is probably because of reduced duration of sunshine hours accumulated to 260 hours during the last 45 days of crop growth (prior to maturity) compared to 300 hours required for optimum growth. With regards to test weight, 10 days old seedlings resulted in intermediate values, whereas 17 days old seedlings gave significantly higher grain weight than 24 days old seedlings. Faruk et al. (2009) also reported that 1000-grain weight was unaffected by age of seedling. In contrast, Gill and Sahi (1987) stated that transplanting of 60 days old seedlings resulted in higher 1000 -grain weight. The positive effects of seedling age on spikelet fertility and grain test weight, however, were not reflected in grain yield of rice which varied in the range of $5245-5416 \mathrm{~kg} / \mathrm{ha}$. The findings were in conformity with results of Krishna and Biradarpatil (2009) where seedling age and planting pattern were not significant on grain yield. Nursery seeding rate did not significantly influence the yield attributes and there by grain and straw yield of rice. It was also seen from the data presented in Table 2 that the varying seed rates did not influence any of the growth parameters significantly. In contrast, Maiti and Bhattacharya (2011) reported the lower seeding rates of 10 and $20 \mathrm{~g} /$ $\mathrm{m}^{2}$ resulted in significant increase in number of tillers and all yield attributing parameters except the 1000 grain weight and ultimately brought increases in gain yield. Interaction effects between seedling ages $\mathrm{x}$ spacing, spacing $x$ seeding rate and seeding rate $\times$ seeding age were not significant on yield attributes and yield except interaction effect of spacing and seeding rate on grain yield. The data presented in Table 3 revealed that 
seeding rate of $40 \mathrm{~g} / \mathrm{m}^{2}$ produced significantly higher grain yield as compared to $25 \mathrm{~g} / \mathrm{m}^{2}$ at $20 \times 15 \mathrm{~cm}$ spacing but the difference was not significant at wider spacing of $20 \times 20 \mathrm{~cm}$. The differences amongst all other seeding rates at both the spacing were also not significant.

Economics: Economic parameters viz. gross return and net return were not significantly influenced due to either seedling ages or the plant spacing. However, B: $\mathrm{C}$ ratio was significantly higher under wider spacing compared to narrow $(20 \times 15 \mathrm{~cm})$ spacing. Cost of cultivation varied significantly amongst various seeding rates with maximum and minimum costs recorded under 25 and $40 \mathrm{~g} / \mathrm{m}^{2}$, respectively. Though, the net returns did not differ significantly amongst seeding rates; 35 and $40 \mathrm{~g} / \mathrm{m}^{2}$ seeding rates remaining statistically alike resulted in significantly higher net returns per rupee invested as compared to 25 and $30 \mathrm{~g} / \mathrm{m}^{2}$ seeding rates. According to Bhandari (1993) minimum B: C ratios of 1.5 for the agricultural sector have been fixed for any enterprise to be economically viable and therefore, a crop enterprise must maintain a $1.5 \mathrm{~B}$ : C ratio to be economically sustainable. Further, Reddy and Reddi (2002) reported that any B: C value greater than 2.0 is considered safe as the farmer gets Rs. 2.00 for every rupee invested.

\section{Conclusion}

Seeding rates of rice nursery did not influence various seedling vigour parameter except seedling shoot length which was significantly higher under all seeding rates than the recommended check $40 \mathrm{~g} / \mathrm{m}^{2}$. However in the final analysis seeding rates had no effect on rice crop productivity and monetary returns. Spacing and seedling age also failed to influence rice crop productivity significantly. Thus there is an ample opportunity to the rice farmer to adopt various SRI components viz., seeding rate, plant spacing and seedling age as per his choice and convenience within the range investigated. Thus, the study clearly indicated that rice under SRI may be raised using 10-24 days old seedling at spacing of $20 \times 20 \mathrm{~cm}$ with nursery seeding rate of $40 \mathrm{~g} / \mathrm{m}^{2}$.

\section{REFERENCES}

Anonymous. (2012-13). Directorate of land Records, Govt. of Himachal Pradesh

Anonymous (2014). Monthly updates of selected rice export prices are available on the FAO Rice Price Update at: http://www.fao.org/economic/RPU [1 ${ }^{\text {th }}$ April, 2014]

AOAC (1970). Methods of Analysis. Association of Official Agricultural Chemists, Washington D.C.

Bhandari, A.S. (1993). Sustainability measures of rice-wheat system across agro-ecological regions in Nepal: Doctoral Dissertation. Central, Luzon State University, Munz, Philippines

FAO (2013). Food and Agriculture Organization of the United Nations. $h t t p: / / F A O S T A T$.fao.org $\left[18^{\text {th }}\right.$ April, 2014].

Faruk, M.O., Rahman, M.A. and Hasan M.A. (2009). Effect of seedling age and number of seedlings per hill on the yield and yield contributing characters of BRRI Dhan 33. International Journal of Sustainable Crop. Production, 4(1): 58-61

Gill, P.S. and Sahi, H.N. (1987). Effect of nitrogen levels in relation to age of seedlings and milling characteristics of rice. Indian Journal of Agricultural Sciences, 57: 630 $-634$

Himeda, M. (1994). Cultivation technique of rice nurseling seedlings: Review of research papers and its future implementation. Agriculture and Horticulture, 69: 679683, 791-796

Kordon, H.A. (1974). Patterns of shoot and root growth in rice seedlings germinating under water. Journal of Applied Ecology, 11: 685-690

Krishna, A., and Biradarpatil N.K. (2009). Influence of seedling age and spacing on seed yield and quality of short duration rice under system of rice intensification cultivation. Karnataka Journal of Agricultural Science, 22 (1): 53-55

Kumar, V.M., Singh, S.D.S., Prabhakarn, N.K. and Thiyagarajan, T.M. (2004). Effect of SRI practices on the yield attributes, yield and water productivity of rice (Oryza sativa). Acta Agronomica Hungarica, 52(4): 399-408

Lima, E. doV., Crusciol, C.A.C and Mateus, G.P. (2010). Participation of main stem and tillers in irrigated rice yield at different seeding densities. Bragantia, 69: 387393

Maiti, P.K. and Bhattacharya, B. (2011). Effect of seeding rate and number of seedlings/hill on the growth and yield of hybrid rice (Oryza sativa) grown in dry (boro) season. Crop. Research, 42(1/2/3): 18-22

Matsuo, T. and Hoshikawa, K. (1993). Science of the Rice Plant: Morphology. Food and Agricultural Policy Research Centre, Tokyo. p 123-132

Menete, M.Z.L., Van Es, H.M., Brito, R.M.L., De Gloria, S.D. and Famba, S. (2008). Evaluation of system of rice intensification (SRI) component practices and their synergies on salt- affected soils. Field Crops Research, 109: $34-44$

Mishra, A. and Salokhe, V.M. (2008). Seedling characterstics and the early growth of transplanted rice under different water regimes. Experimental Agriculture, 44: 1 $-19$

Mobasser, H.R., Tari, D.B., Vojdani, M., Abadi, R.S. and Eftekhari, A. (2007). Effect of seedlings age and planting space on yield and yield components of rice (Neda Variety). Asian Journal of Plant Science, 6(2): 438-440

More, M.R., Pawar, L.G., Chavan, S.A., Chavan, P.G. and Misal, R.M. (2007). Effect of methods of raising seedlings and seedlings age and transplanting on growth and yield of rice. In: System of Rice Intensification in IndiaProgress and Prospects (Gujja et al., eds.) Second National Symposium, October 3-5, Agartala, Tripura, India, p 62-65

Olsen's S.R., Cole C.V., Watanube F.S. and Dean L.A. 1954. Estimation of Available Phosphorus in Soil by Extraction with NaHCO3. USDA, circ 939: 19-33

Rahman, M.M. (2001). Effect of seedling age and spacing on the productivity of hybrid rice Sonarbangla-1. M Sc Thesis, Department of Agronomy, BAU, Mymensingh

Rajesh, V. and Thanunathan, K. (2003). Effect of seedling age, number, spacing on yield and nutrient uptake of traditional Kambanehanba rice. Madras Agricultural 
Journal, 90: 47-49

Reddy S. (2004). Agronomy of field crops. Kalyani Publishers, New Delhi, India

Reddy, T.Y. and Reddi, G.H. (2002). Principles of Agronomy, Kalyani Publishers, New Delhi, India. p 54-326

Sasaki, R. (2004). Characteristics and seedlings establishment of rice nurseling seedlings. Japanese Agricultural Research Quarterly, 38: 7-1

Satayanarayana, A., Thiyagarajan, T.M. and Uphoff, N.
(2007). Opportunities for water saving with higher yield from the system of rice intensification. Irrigation Science, 25: 99-115

Subbiah B.V. and Asija G.L. (1956). A rapid procedeure for estimation of available $\mathrm{N}$ in soils. Current Science, 25: 259-260

TeKrony, D.M. and Egli, D.B. (1991). Relationship of seed vigour to crop yield: A review. Crop. Science, 31: 816-822 